\title{
INCLUSÃO DA PESSOA COM DEFICIÊNCIA NO MERCADO DE TRABALHO: COTAS NAS EMPRESAS E PROTEÇÃO CONTRA A DISPENSA NA SOCIEDADE DA INFORMAÇÃO
}

\author{
INCLUSION OF DISABLED PERSON IN THE LABOR MARKET: QUOTAS IN \\ COMPANIES AND PROTECTION AGAINST DISMISSAL IN THE INFORMATION \\ SOCIETY
}

Flávia Piva Almeida Leite

\begin{abstract}
Doutora em Direito Urbanístico pela Pontifícia Universidade Católica - PUC - São Paulo/SP, Mestre em Direito Constitucional pela Instituição Toledo de Ensino - ITE Bauru/SP, Pós-graduada em Gerente de Cidades pela Fundação Armando Álvares Penteado - FAAP - São Paulo/SP. Membro da Comissão de Infraestrutura, Logística e Desenvolvimento Sustentável da OAB/SP. Professora do Mestrado em Direito da Sociedade da Informação e da Graduação do Centro Universitário das Faculdades Metropolitanas Unidas. Avaliadora do CONPEDI. Advogada e palestrante.

E-mail: flaviaaleite3@ hotmail.com
\end{abstract}

Gustavo Filipe Barbosa Garcia

Livre-Docente pela Faculdade de Direito da Universidade de São Paulo. Doutor em Direito pela Faculdade de Direito da Universidade de São Paulo. Pós-Doutorado em Direito pela Universidade de Sevilla. Especialista em Direito pela Universidade de Sevilla.

Membro da Academia Brasileira de Direito do Trabalho. Membro Pesquisador do IBDSCJ. Professor do Mestrado em Direito da Sociedade da Informação e da Graduação do Centro Universitário das Faculdades Metropolitanas Unidas. Professor Titular do Centro Universitário do Distrito Federal (UDF). Professor da Faculdade de Direito da

Universidade Presbiteriana Mackenzie. Advogado. E-mail: gustavofbg@yahoo.com.br

Recebido em: 19/12/2016

Aprovado em: 20/03/2017

Doi: $10.5585 / \mathrm{rdb} . v 17 \mathrm{i} 7.566$

RESUMO: O presente estudo tem como objetivo a análise da inclusão da pessoa com deficiência no mercado de trabalho, considerando o contexto contemporâneo da sociedade da informação. De modo mais específico, este artigo examina as técnicas previstas no sistema jurídico para a concretização do direito fundamental ao trabalho do mencionado grupo que se caracteriza pela maior vulnerabilidade social. Analisa-se, assim, a previsão legal de cumprimento de cotas pelas empresas na contratação de trabalhadores, bem como a proteção contra a despedida de empregados reabilitados e com deficiência. Conclui-se que os referidos mecanismos, apesar relevantes, não são suficientes para o efetivo acesso e a inclusão dessas pessoas no mercado de trabalho, tornando necessários outros institutos, como a qualificação profissional, de modo a se concretizar a isonomia material no plano das relações sociais e de trabalho.

Palavras-Chave: Sociedade da informação. Pessoa com deficiência. Mercado de trabalho. Acessibilidade. Inclusão.

ABSTRACT: The present study aims to analyze the inclusion of people with disabilities in the labor market, considering the contemporary context of the information society. More specifically,

Revista de Direito Brasileira | São Paulo, SP | v. 17 | n. 7 | p. 245 - 260 | Mai./Ago. 2017 
this article examines the techniques that are provided in legal system for the realization of the fundamental right to work of the group that is characterized by greater social vulnerability. It analyzes, therefore, the legal forecast of quota compliance by companies in hiring workers, as well as protection against dismissal of rehabilitated and disabled employees. It is concluded that these mechanisms, although relevant, are not sufficient for the effective access and inclusion of these people in the labor market, making necessary other institutes, such as professional qualification, in order to materialize the material isonomy in the social and work relations.

Key-Words: Information society. Disabled person. Labor market. Accessibility. Inclusion.

SUMÁRIO: Introdução; 1. O ambiente contemporâneo da sociedade da informação; 2. A inclusão das pessoas com deficiência na sociedade da informação; 3. Inclusão da pessoa com deficiência no trabalho: cotas nas empresas e proibição de despedida; Considerações finais; Referências.

\section{INTRODUÇÃO}

A preocupação da sociedade quanto às pessoas que apresentam alguma forma deficiência não vem de hoje. Ainda assim, sem dúvida, não deixa de ser relativamente recente a melhor conscientização social e jurídica do problema que enfrentam essas pessoas.

Nessa linha de observações, considerando o atual contexto da assim chamada sociedade da informação, o presente estudo é voltado a analisar a relevância e as principais formas de inclusão das pessoas com deficiência no mercado de trabalho.

Com esse objetivo, primeiramente, serão verificados os aspectos essenciais relacionados à sociedade contemporânea e a necessidade de inclusão das pessoas com deficiência nas diversas esferas de convívio social.

Posteriormente, tendo em vista os objetivos propostos, cabe examinar, de modo específico, as formas essenciais de se concretizar o direito social ao trabalho do mencionado grupo, com destaque à exigência legal de cumprimento de cotas pelas empresas e a proteção contra a dispensa de empregados nessa condição de maior vulnerabilidade.

Para se alcançar esse desiderato, serão utilizados os métodos de pesquisa doutrinária, legislativa e jurisprudencial. Procura-se, com isso, enfrentar as principais questões voltadas a essa temática, o que permitirá concluir a respeito da parcial efetividade dos referidos mecanismos de inclusão e de manutenção das pessoas com deficiência no âmbito laboral.

\section{O AMBIENTE CONTEMPORÂNEO DA SOCIEDADE DA INFORMAÇÃO}

Vivemos em uma atual sociedade baseada essencialmente no desenvolvimento e na disseminação das tecnologias e da comunicação.

Surge, assim, a sociedade da informação, ou sociedade da comunicação, como prefere denominá-la o professor José de Oliveira Ascensão (1999, 163-184), ou ainda sociedade do conhecimento, como revela o filósofo Pierre Lévy, um dos autores de maior envergadura a respeito da matéria ${ }^{1}$.

\footnotetext{
${ }^{1}$ Pierre Lévy escreveu os seguintes livros já traduzidos para o nosso vernáculo: As tecnologias da inteligência: o futuro do pensamento na era da informática. Rio de Janeiro, Editora 34, 1993; As árvores de conhecimentos. São Paulo: Escuta, 1995 (em coautoria com Michel Authier); O que é o virtual? São Paulo: Editora 34, 1996; A ideografia dinâmica: para uma imaginação artificial? Lisboa: Instituto Piaget, 1997; A ideografia dinâmica: rumo a uma imaginação artificial? São Paulo: Loyola, 1998; A máquina universo: criação, cognição e cultura informática. São Paulo: Artmed, 1998; Cibercultura. Tradução de Carlos Irineu da Costa. São Paulo: Editora 34, 2001; A inteligência coletiva: por uma antropologia do ciberespaço. 3. ed. São Paulo: Loyola, 2000; Filosofia world: o mercado, o ciberespaço, a consciência. Lisboa: Instituto Piaget, 2000; A Conexão Planetária: o mercado, o
} Revista de Direito Brasileira | São Paulo, SP | v. 17 | n. 7 | p. 245 - 260 | Mai./Ago. 2017 
Do mesmo modo como a Revolução Industrial modificou as feições do mundo, a ainda incipiente Revolução Digital certamente irá transformar as faces do planeta.

O surgimento dessa nova sociedade trouxe, portanto, a necessidade de se repensar importantes aspectos relativos à organização social e o papel do Estado nesse novo contexto.

Essa necessidade fez com que a questão da inclusão das minorias étnicas, culturais e de gênero tomasse relevo e passasse a ser reconhecida em documentos nacionais e internacionais. Esse novo paradigma social traz como princípios o reconhecimento e a valorização da diversidade humana, a solidariedade humanitária, a igual importância desses grupos, o que motivou as pessoas com deficiência a se organizarem e promoverem um forte movimento de participação política e social no âmbito do processo de redemocratização do Brasil.

Nessa perspectiva, a Constituição Federal de 1988 inaugurou novas feição e estrutura ao Estado brasileiro, uma vez que não somente o consagrou democrático, mas também ressaltou o seu caráter essencialmente social, ao fundá-lo em valores como a dignidade humana e a cidadania, que repercutem sobre o ordenamento como um todo e ao mesmo tempo serve de norte para toda e qualquer iniciativa privada e pública.

Ademais, o Brasil, na busca pela concretização dos direitos das pessoas com deficiência, inclusive quanto à acessibilidade aos meios de comunicação e às novas tecnologias, assinou, em 30 de março de 2007, a Convenção Internacional sobre os Direitos das Pessoas com Deficiência e seu Protocolo Facultativo, no âmbito da Organização das Nações Unidas. A sua aprovação pelo Congresso Nacional ocorreu por meio do Decreto Legislativo 186/2008, tendo sido promulgada pelo Decreto 6.949, de 25 de agosto de $2009^{2}$.

Para concretizar os direitos das pessoas com deficiência, foi promulgada no Brasil a Lei 13.146, de 06 de julho de 2015, tendo instituído a Lei Brasileira de Inclusão da Pessoa com Deficiência (Estatuto da Pessoa com Deficiência), que, em seu Livro I (Parte Geral), Título II (Dos Direitos Fundamentais), no Capítulo VI, assegura o direito ao trabalho, habilitação profissional e reabilitação profissional e à sua inclusão nesse setor ${ }^{3}$.

Porém, para que haja uma sociedade verdadeiramente democrática, isto é, que realize o direito de todos, e não apenas da maioria, temos que concretizar com eficiência a tão almejada inclusão social. Não é uma tarefa fácil entender o seu real significado, pois um de seus princípios, segundo preceitua Sassaki ${ }^{4}$, é a rejeição zero, também conhecida como exclusão zero. Isto quer dizer que ou se adere totalmente aos seus princípios, ou não se fala em inclusão.

\section{A INCLUSÃO DAS PESSOAS COM DEFICIÊNCIA NA SOCIEDADE DA INFORMAÇÃO}

O processo de globalização diminuiu sensivelmente a distância existente entre os países e aproximou as pessoas. Passamos, efetivamente, da era atômica à era digital ${ }^{5}$. Esther Morón descreve, com felicidade, esse atual fenômeno:

ciberespaço, a consciência. São Paulo: Editora 34, 2001; Ciberdemocracia. Lisboa: Instituto Piaget, 2003 ; O futuro da internet. São Paulo: Paulus, 2010; O fogo liberador. São Paulo: Iluminuras, 2007. Neles fica absolutamente transparente que se trata de um dos maiores estudiosos da vida digital, analisando o fenômeno da internet sob uma perspectiva claramente humanista.

2 BRASIL. Decreto 6.949, de 25 de agosto de 2009. Brasília, 2009 . Disponível em: <http://www.planalto.gov.br/ccivil_03/_ato2007-2010/2009/decreto/d6949.htm>. Acesso em: 13 mar. 2017.

3 BRASIL. Lei 13.146, de 6 de julho de 2015. Brasília, 2015. Disponível em: <http://www.planalto.gov.br/ccivil_03/_ato2015-2018/2015/Lei/L13146.htm>. Acesso em: 13 mar. 2017.

${ }^{4}$ SASSAKI, Romeu Kazumi. Inclusão: construindo uma sociedade para todos. 3. ed. Rio de Janeiro: Editora WVA, 1999. p. 50.

${ }^{5}$ Observa, a propósito, Marco Aurélio Greco: “A atual revolução tecnológica pode ser resumida no reconhecimento de que estamos passando 'dos átomos para os bits'. O que isso significa? Os átomos serviam de meio físico para transporte e comunicação de mensagens no sentido de que 'contrato' tanto significava o vínculo jurídico como o

Revista de Direito Brasileira | São Paulo, SP | v. 17 | n. 7 | p. 245 - 260 | Mai./Ago. 2017 
Para pode apreciar las ventajas y consecuencias de 'ser digital', aconséjase reflexionar sobre la diferencia entre átomos y bits. Como ya se afirmó, la mayor parte de la información nos llega en forma de átomos: libros, periódicos, revistas. El mundo es hecho de átomos. Un bit no tiene color, tamaño ni peso. Es el DNA de la información. Es tan solamente un número, cuya representación más elemental es una secuencia de ceros y unos. Los bits siempre fueron el elemento básico de la información pero en los últimos veinticinco años se han conseguido digitalizar cada vez más tipos de información, auditiva y visual, por ejemplo, reduciéndolos de igual manera a números.

Digitalizar significa convertir en números lo que se quiere transmitir. La digitalización permite que distintos tipos de datos y de información, como textos, voz e imágenes puedan convertirse en números, ser tratados del mismo modo y transmitidos por las mismas lineas. El fenómeno multimidia o hipermidia es el resultado de la digitalización de todos los tipos de señales.

La digitalización de la información es un concepto llave para entender las nuevas tecnologías y su generalización ha operado una división radical entre el analógico y el digital. El mundo digital es el mundo de la información convertida en dígitos y el mundo analógico es el restante ${ }^{6}$.

Esse processo se deu tanto do ponto de vista econômico, como no setor de comunicação, principalmente, em razão da criação da internet. As barreiras físicas, culturais e econômicas que separavam as pessoas foram derrubadas pela internet, que possibilitou às pessoas que se encontravam geograficamente distantes se comunicarem rápida e facilmente.

Essa transformação nos meios de comunicação facilitou sobremaneira a concretização do direito fundamental à informação e ao conhecimento, possibilitando que a pessoa de sua própria casa ou usando o celular possa se conectar ao mundo. A velocidade da circulação da informação que a internet possibilitou foi outro fator preponderante para diminuição das barreiras. Desse modo, no que diz respeito à comunicação, houve uma mudança de paradigma, uma vez que as informações deixaram de ser transmitidas exclusivamente pela imprensa escrita, ou pelo rádio e televisão, e passaram a ser compartilhadas por milhares de pessoas por meio da internet.

A transição que vivemos é evidente. Como mencionamos, se a Revolução Industrial modicou as feições do mundo, a Revolução Digital está modificando nosso dia a dia. A diferença entre uma e outra está na velocidade surpreendentemente maior com que referidas transformações ocorrem durante a segunda. Enquanto na sociedade industrializada era a quantidade de trabalho investida nos produtos e serviços que servia de paradigma de valor, na sociedade digitalizada será a quantidade de informação e de conhecimento que tais produtos e serviços conseguirem agregar que determinará a formação do novo paradigma.

Surge, assim, uma nova era do desenvolvimento humano, baseada não só na valoração da informação, como no impacto das tecnologias sobre as relações sociais, humanas, empresariais, governamentais, entre outras.

documento redigido em papel (ou pergaminho) revestido de certas formalidades. Os átomos do papel eram o meio físico para transmitir a mensagem 'jurídica' da criação das relações, obrigações etc. Uma nova civilização está em criação; nesta, o conceito relevante não é mais o de átomo, mas sim o de bit, o que traz profunda alteração na estrutura das relações e na relevância dos projetos, pois a mensagem se desatrela do meio físico passando a ter vida própria independente de estar superposta a átomos" (Transações eletrônicas: aspectos jurídicos. Revista de Direito Bancário do Mercado de Capitais e da Arbitragem, São Paulo, RT, v. 8, p. 69, abr./jun. 2000).

${ }^{6}$ MORÓN LERMA, Esther. Internet y Derecho Penal: "hacking" y otras conductas ilícitas en la red. Revista de Derecho y Processo Penal, Pamplona, Aranzadi, n. 1, 1999, p. 79.

Revista de Direito Brasileira | São Paulo, SP | v. 17 | n. 7 | p. 245 - 260 | Mai./Ago. 2017 
A sociedade da informação pode ser compreendida como um ambiente que se apresenta no âmbito de um novo ciclo histórico posterior à pós-modernidade. A sua característica principal é exatamente a transformação sofrida nas sociedades contemporâneas, gerada pela revolução digital e pelo expressivo impacto da tecnologia, tanto nas relações humanas como nas relações empresariais, sociais e governamentais, contribuindo para o surgimento de complexas redes profissionais e tecnológicas voltadas à produção e ao uso da informação com potencialidade para gerar conhecimento, desenvolvimento e inclusão, notadamente, quanto ao presente estudo, da pessoa com deficiência no mercado de trabalho.

Assim, não apresentamos um conceito fechado de sociedade da informação, a exemplo de Garcia Marques e Lourenço Martins ${ }^{7}$, ao mencionarem que a sociedade de informação expressão que cada vez importa menos definir, na medida em que se vai vivendo em maior escala - assenta-se sobre o uso ótimo das novas tecnologias da informação e da comunicação, em respeito aos princípios democráticos, da igualdade e da solidariedade, visando o reforço da economia e da prestação de serviços públicos, e, afinal, a melhoria da qualidade de vida de todos os cidadãos.

O presente estudo propõe verificar as disposições do sistema jurídico relativas ao tema, realçando que as atividades desenvolvidas no ambiente da sociedade da informação devem se harmonizar com a valorização dos direitos humanos. Procura-se analisar como o ordenamento jurídico estabelece a inclusão das pessoas com deficiência, ainda que de forma parcial, por meio de colocação competitiva e em igualdade de oportunidades com as demais pessoas.

Assim, para que haja uma sociedade que concretize o direito de todos, e não apenas da maioria, temos que assegurar, com efetividade, a tão almejada inclusão social. Para que haja a verdadeira inclusão, deve ser contemplado o direito ao acesso das pessoas com deficiência ao mercado de trabalho.

Segundo Sassaki, a inclusão social pode ser conceituada como um processo pelo qual a sociedade se adapta para poder incluir as pessoas com deficiência e, simultaneamente, estas se preparam para assumir seus papeis na sociedade Consequentemente, a inclusão social é um processo de mão dupla, ou seja, tanto a pessoa com deficiência como a sociedade precisam se modificar $^{8}$.

A Constituição Federal de 1988 não destoou dessa evolução que já vinha operando no mundo todo. Consagrou em diversas passagens a proteção da pessoa com deficiência, no sentido de assegurar a sua inclusão social. São reforçadas as normas que asseguram a dignidade da pessoa humana (artigo $1^{\circ}$, inciso III), a cidadania (artigo $1^{\circ}$, inciso I) e a igualdade $\left(\operatorname{artigo} 5^{\circ}\right)^{9}$, seguidas por diversas leis protetivas que visam reconhecer a inclusão dessas pessoas na sociedade.

O Brasil, na busca pela concretização dos direitos das pessoas com deficiência, inclusive do direito à acessibilidade aos meios de comunicação e novas tecnologias, ratificou a já mencionada Convenção sobre os Direitos das Pessoas com Deficiência e seu Protocolo Facultativo, de 2007. Frise-se que esse foi o primeiro tratado de direitos humanos que cumpriu os termos do $\S 3^{\circ}$ do artigo $5^{\circ}$ da Constituição Federal de 1988 , tendo status equivalente a emenda constitucional, como se observa do Decreto-legislativo 186/2008, que aprovou a norma internacional em questão.

A principal contribuição dessa Convenção é a positivação da mudança de paradigma da visão da deficiência no mundo, que passa do modelo médico, no qual a deficiência é tratada como um problema de saúde, para o modelo social dos direitos humanos, no qual a deficiência é

\footnotetext{
${ }^{7}$ MARQUES, Garcia; MARTINS, Lourenço. Direito da informática. Coimbra: Almedina, 2000. p. 43.

${ }^{8}$ SASSAKI, Romeu Kazumi. Inclusão: construindo uma sociedade para todos. 3. ed. Rio de Janeiro: Editora WVA, 1999. p. 41.

9 BRASIL. Constituição da República Federativa do Brasil de 1988. Brasília, 1988. Disponível em: <http://www.planalto.gov.br/ccivil_03/constituicao/constituicaocompilado.htm>. Acesso em: 13 mar. 2017.
}

Revista de Direito Brasileira | São Paulo, SP | v. 17 | n. 7 | p. 245 - 260 | Mai./Ago. 2017 
resultante de uma equação que tem duas variáveis, quais sejam: as limitações funcionais do corpo humano e, no caso deste trabalho, das barreiras relacionadas ao ambiente laboral.

Todos os direitos garantidos pela Convenção sobre os Direitos das Pessoas com Deficiência, a partir desse novo paradigma positivado, têm o intuito de emancipar as pessoas com deficiência, permitindo o pleno gozo e o efetivo exercício de seus direitos e garantias fundamentais.

Tanto que, em seu preâmbulo, registra ser a deficiência um conceito em evolução e que resulta da interação entre as pessoas com deficiência e as barreiras ambientais que impedem sua plena e efetiva participação na sociedade em igualdade de oportunidades com as demais pessoas. Portanto, ao ter reconhecido que a deficiência é um conceito em evolução, constatou-se que essas pessoas têm capacidades e que, se elas tiverem informações e comunicações acessíveis, terão oportunidades que até então não puderam vivenciar.

Assim, a Convenção, ao reconhecer o modelo social como o mais novo paradigma para conceituar as pessoas com deficiência, consolida a acessibilidade tanto como princípio, como direito. E, como princípio-direito, obriga os Estados à sua concretização como garantia fundamental, extremamente relevante para a concretização dos direitos humanos das pessoas com deficiência ${ }^{10}$.

Considerando a acessibilidade como condição de livre acesso, de aproximação, de utilização, do manuseio de qualquer objeto, local, ou condição, é seu objetivo proporcionar a todas as pessoas, e, principalmente às pessoas com deficiência, um ganho de autonomia e de mobilidade, para que possam usufruir dos espaços com mais segurança, confiança e comodidade. E para que isso ocorra, a Convenção determina que todos os ambientes eliminem as barreiras existentes, especialmente as que forem criadas pelo próprio ser humano, e que novos espaços sejam desenhados livres de barreiras, para não obstaculizar o pleno gozo e exercício dos direitos das pessoas com deficiência.

Portanto, a acessibilidade é a possibilidade e a condição de alcance, percepção, entendimento e interação para a utilização, a participação e a contribuição, em igualdade de oportunidades, com segurança e autonomia, independentemente de sua capacidade motora, visual, auditiva, intelectual, cultural ou social, a qualquer momento, em qualquer local e em qualquer ambiente físico ou computacional e a partir de qualquer dispositivo de acesso. Assim, o trabalho deve ser desenvolvido em ambiente acessível e inclusivo. Esse ambiente acessível é o propósito máximo da norma internacional, uma vez que ele, em suas concepções físicas (espaços arquitetônicos, mobiliários, equipamentos urbanos, transportes, informação e comunicação) e humanas (atitudes e procedimentos), é que permite (ou não) o exercício pleno e equitativo de todos os direitos, inclusive ao trabalho.

Por ser um processo de transformação do ambiente e desenvolver-se a partir do reconhecimento social de que a deficiência é resultante do desajuste entre as características físicas, psíquicas ou sensoriais das pessoas e as condições em que elas atuam, a acessibilidade passa a ser retomada como um tema de grande importância para a vida em sociedade.

A acessibilidade, portanto, constituiu-se em direito instrumental, uma vez que sem acesso aos equipamentos urbanos, às escolas, aos postos de saúde, aos transportes públicos e, quanto ao presente estudo, ao trabalho, as pessoas com deficiência não podem exercer, plenamente, a sua cidadania. Não há inclusão social e exercício da cidadania sem acessibilidade.

A presença da acessibilidade no meio urbano, bem como nas edificações, nos transportes, na informação e comunicação, inclusive quanto ao direito ao trabalho e nas suas mútuas interações, é uma exigência constitucional. Surge, atualmente, de acordo com a

\footnotetext{
${ }^{10}$ Especificamente o disposto no preâmbulo da Convenção, alínea "v". Bem como o artigo $3^{\circ}$, "f", que define a acessibilidade como um dos princípios gerais a reger a Convenção. E no artigo $9^{\circ}$, trata da acessibilidade como um direito, inclusive obrigando os Estados a tomarem medidas apropriadas para assegurá-lo.
}

Revista de Direito Brasileira | São Paulo, SP | v. 17 | n. 7 | p. 245 - 260 | Mai./Ago. 2017 
Convenção sobre o Direito das Pessoas com Deficiência, como um direito forte, o que impacta na concepção contemporânea dos direitos humanos e impõe a sua releitura sob essa nova perspectiva.

Em consonância com esse direito fundamental ao acesso, a já mencionada Lei 13.146/2015, que institui a Lei Brasileira de Inclusão da Pessoa com Deficiência (Estatuto da Pessoa com Deficiência), traz avanços importantes quanto aos direitos do trabalhador com deficiência. Em capítulo reservado ao direito ao trabalho, em seus artigos 34 a 38, contempla regras específicas para as relações de trabalho, desde a formação profissional e o recrutamento, até as condições de contratação em um emprego competitivo, incluído o emprego apoiado.

Agregam-se à obrigatória implantação da acessibilidade dois outros elementos essenciais para que $\mathrm{o}$ trabalhador com deficiência desempenhe as suas atividades laborativas adequadamente: o fornecimento de recursos de tecnologia assistiva ${ }^{11}$ e a adaptação razoável ${ }^{12}$.

Portanto, o trabalho deve ser desenvolvido em ambiente acessível e inclusivo. Esse é o principal dever inserido na Lei Brasileira de Inclusão da Pessoa com Deficiência. Nesse sentido, assim discorre Maria Aparecida Gugel ao tratar do tema:

A importância do ambiente em relação à pessoa com deficiência é tanta que a interação das diferentes naturezas de deficiência que a interação das diferentes naturezas de deficiência (física, mental, intelectual ou sensorial) com as barreiras é que proporciona a medida de sua participação na vida em sociedade em igualdade de condições com as demais pessoas. Portanto, para os ambientes de trabalho não poderia ser diferente, lembrando que as atividades de trabalho (ofício, cargo ou função), não importam quais sejam elas, devem estar concebidas sempre em condições plenas e adequadas de saúde, higiene e segurança para o trabalhador, sendo que para o trabalhador com deficiência as questões técnicas de acessibilidade são sempre implicitamente exigidas ${ }^{13}$.

Como se pode notar, a partir dos objetivos da denominada sociedade de informação, mostra-se, prontamente, o seu compromisso com a difusão e a integração das tecnologias de informação para a melhoria da qualidade de vida e para o crescimento sustentável da sociedade, bem como a inclusão da pessoa com deficiência no trabalho por meio da sua inserção competitiva, em igualdade de oportunidades com as demais pessoas.

\section{INCLUSÃO DA PESSOA COM DEFICIÊNCIA NO TRABALHO: COTAS NAS EMPRESAS E PROIBIÇÃO DE DESPEDIDA}

O Estatuto da Pessoa com Deficiência (Lei 13.146/2015) determina, em seu artigo 37, que o modo de inclusão da pessoa com deficiência no trabalho ocorre por meio da colocação competitiva em igualdade de oportunidades com as demais pessoas. Devem ser seguidas todas as regras de contratação na legislação trabalhista e previdenciária, observado o cumprimento de

\footnotetext{
${ }^{11}$ A tecnologia assistiva ou ajuda técnica, conforme artigo $3^{\circ}$, inciso III, da Lei 13.146/2015, consiste em produtos, equipamentos, dispositivos, recursos metodológicos, estratégias, práticas e serviços que objetivem promover a funcionalidade, relacionada à atividade visando à sua autonomia e independência.

${ }^{12}$ Por adaptação razoável entenda-se as adaptações, as modificações e os ajustes necessários e adequados que não acarretem ônus desproporcional e indevido, quando requeridos em cada caso, a fim de assegurar que a pessoa com deficiência possa gozar ou exercer, em igualdade de condições e oportunidades com as demais pessoas, todos os direitos e liberdades fundamentais (artigo $3^{\circ}$, inciso IV, da Lei 13.146/2015).

${ }^{13}$ GUGEL, Maria Aparecida. Do Direito ao Trabalho. In: LEITE, Flávia Piva Almeida; RIBEIRO, Lauro Luiz Gomes; COSTA FILHO, Waldir Macieira (Coord.). Comentários ao Estatuto da Pessoa com Deficiência. São Paulo: Saraiva, São Paulo, 2016. p. 185.
}

Revista de Direito Brasileira | São Paulo, SP | v. 17 | n. 7 | p. 245 - 260 | Mai./Ago. 2017 
todas as normas e técnicas de acessibilidade, fornecimento de recursos de tecnologia assistiva e de adaptação razoável, se necessária para cada caso ${ }^{14}$.

Em consonância com o direito de acesso ao trabalho pela pessoa com deficiência, a Lei 8.213/1991, no artigo 93, determina que a empresa com 100 ou mais empregados é obrigada a preencher de $2 \%$ a $5 \%$ dos seus cargos com beneficiários reabilitados ou pessoas com deficiência habilitadas, na seguinte proporção:

$$
\begin{aligned}
& \text { I - até } 200 \text { empregados........2\%; } \\
& \text { II - de } 201 \text { a } 500 \ldots \ldots \ldots \ldots \ldots \ldots . .3 \% \\
& \text { III - de } 501 \text { a } 1.000 \ldots \ldots \ldots \ldots . . . . .4 \% \\
& \text { IV - de } 1.001 \text { em diante.......5\% }
\end{aligned}
$$

Cabe esclarecer que para a reserva de cargos deve ser considerada somente a contratação direta de pessoa com deficiência, ficando excluído o aprendiz com deficiência de que trata a Consolidação das Leis do Trabalho (arts. $428, \S \S 3^{\circ}, 5^{\circ}$ e $8^{\circ}$, e 429 ).

Ademais, nos termos do artigo 16-A da Lei $7.573 / 1986^{16}$, acrescentado pela Lei $13.194 / 2015$, os marítimos $^{17}$ exercendo atividades embarcadas, por serem submetidos às exigências contidas em convenções e acordos internacionais ratificados pelo Brasil, relativas às condições físicas, médicas e psicológicas, não integram a soma dos trabalhadores das empresas de navegação para o disposto no artigo 93 da Lei 8.213/1991.

Incumbe ao Ministério do Trabalho estabelecer a sistemática de fiscalização, bem como gerar os dados e as estatísticas sobre o total de empregados e as vagas preenchidas por pessoas com deficiência e por beneficiários reabilitados da Previdência Social, fornecendo-os, quando solicitados, aos sindicatos, às entidades representativas dos empregados ou aos cidadãos interessados (artigo 93, $\S 2^{\circ}$, da Lei 8.213/1991) ${ }^{18}$.

Quanto à definição de pessoa com deficiência, o artigo $4^{\circ}$ do Decreto 3.298/1999, com as alterações do Decreto 5.296/2004, que regulamenta a Lei 7.853/1989, assim prevê:

Art. $4^{\circ}$. É considerada pessoa portadora de deficiência a que se enquadra nas seguintes categorias:

I - deficiência física - alteração completa ou parcial de um ou mais segmentos do corpo humano, acarretando o comprometimento da função física, apresentandose sob a forma de paraplegia, paraparesia, monoplegia, monoparesia, tetraplegia, tetraparesia, triplegia, triparesia, hemiplegia, hemiparesia, ostomia, amputação ou ausência de membro, paralisia cerebral, nanismo, membros com deformidade congênita ou adquirida, exceto as deformidades estéticas e as que não produzam

14 BRASIL. Lei 13.146, de 6 de julho de 2015. Brasília, 2015. Disponível em: <http://www.planalto.gov.br/ccivil_03/_ato2015-2018/2015/Lei/L13146.htm>. Acesso em: 13 mar. 2017.

15 BRASIL. Lei 8.213, de 24 de julho de 1991. Brasília, 1991. Disponível em: <http://www.planalto.gov.br/ccivil_03/leis/L8213compilado.htm>. Acesso em: 13 mar. 2017.

16 BRASIL. Lei 7.573, de 23 de dezembro de 1986. Brasília, 1986. Disponível em: <http://www.planalto.gov.br/ccivil_03/leis/1980-1988/L7573.htm>. Acesso em 13 mar. 2017.

${ }^{17}$ Conforme o artigo $1^{\circ}$, inciso I, do Regulamento de segurança do tráfego aquaviário em águas sob jurisdição nacional, aprovado pelo Decreto 2.596/1998, os marítimos compõem o $1^{\circ}$ Grupo dos aquaviários e são "tripulantes que operam embarcações classificadas para navegação em mar aberto, apoio portuário e para a navegação interior nos canais, lagoas, baías, angras, enseadas e áreas marítimas consideradas abrigadas” (BRASIL. Decreto 2.596, de 18 de maio de 1998. Brasília, 1998. Disponível em: <http://www.planalto.gov.br/ccivil_03/decreto/D2596.htm>. Acesso em: 13 mar. 2017). Aquaviário, por sua vez, é "todo aquele com habilitação certificada pela autoridade marítima para operar embarcações em caráter profissional” (artigo 2º inciso II, da Lei 9.537/1997. BRASIL. Lei 9.537, de 11 de dezembro de 1997. Brasília, 1997. Disponível em: <http://www.planalto.gov.br/ccivil_03/leis/19537.htm>. Acesso em: 13 mar. 2017).

${ }^{18}$ Cf. DELGADO, Mauricio Godinho. Curso de direito do trabalho. 15. ed. São Paulo: LTr, 2016. p. $585-586$. Revista de Direito Brasileira | São Paulo, SP | v. 17 | n. 7 | p. 245 - 260 | Mai./Ago. 2017 
dificuldades para o desempenho de funções; (redação dada pelo Decreto 5.296, de 2004)

II - deficiência auditiva - perda bilateral, parcial ou total, de quarenta e um decibéis $(\mathrm{dB})$ ou mais, aferida por audiograma nas frequências de $500 \mathrm{HZ}$, $1.000 \mathrm{HZ}, 2.000 \mathrm{~Hz}$ e $3.000 \mathrm{~Hz}$; (redação dada pelo Decreto 5.296, de 2004)

III - deficiência visual - cegueira, na qual a acuidade visual é igual ou menor que 0,05 no melhor olho, com a melhor correção óptica; a baixa visão, que significa acuidade visual entre 0,3 e 0,05 no melhor olho, com a melhor correção óptica; os casos nos quais a somatória da medida do campo visual em ambos os olhos for igual ou menor que $60^{\circ}$; ou a ocorrência simultânea de quaisquer das condições anteriores; (redação dada pelo Decreto 5.296, de 2004)

IV - deficiência mental - funcionamento intelectual significativamente inferior à média, com manifestação antes dos dezoito anos e limitações associadas a duas ou mais áreas de habilidades adaptativas, tais como:

a) comunicação;

b) cuidado pessoal;

c) habilidades sociais;

d) utilização dos recursos da comunidade; (redação dada pelo Decreto 5.296, de 2004)

e) saúde e segurança;

f) habilidades acadêmicas;

g) lazer; e

h) trabalho;

V - deficiência múltipla - associação de duas ou mais deficiências ${ }^{19}$.

Não obstante, na atualidade, de modo mais abrangente, considera-se pessoa com deficiência aquela que tem impedimento de longo prazo de natureza física, mental, intelectual ou sensorial, o qual, em interação com uma ou mais barreiras, pode obstruir sua participação plena e efetiva na sociedade em igualdade de condições com as demais pessoas (artigo $2^{\circ}$ da Lei 13.146/2015, que instituiu o Estatuto da Pessoa com Deficiência ${ }^{20}$.

O mencionado diploma legal tem como base a mencionada Convenção sobre os Direitos das Pessoas com Deficiência e seu Protocolo Facultativo, ratificados pelo Congresso Nacional por meio do Decreto Legislativo 186/2008, em conformidade com o procedimento previsto no artigo $5^{\circ}, \S 3^{\circ}$, da Constituição da República, em vigor para o Brasil, no plano jurídico externo, desde 31 de agosto de 2008, e promulgados pelo Decreto 6.949/2009 ${ }^{21}$, publicado no Diário Oficial da União de 26.08.2009, data de início de sua vigência no plano interno.

O artigo $7^{\circ}$, inciso XXXI, da Constituição Federal de 1988 estabelece a proibição de qualquer discriminação quanto a salário e critérios de admissão do trabalhador com deficiência ${ }^{22}$.

Nesse contexto, a pessoa com deficiência tem direito ao trabalho de sua livre escolha e aceitação, em ambiente acessível e inclusivo, em igualdade de oportunidades com as demais pessoas (artigo 34 da Lei 13.146/2015) ${ }^{23}$.

Desse modo, as pessoas jurídicas de direito público, privado ou de qualquer natureza são obrigadas a garantir ambientes de trabalho acessíveis e inclusivos.

19 BRASIL. Decreto 3.298, de 20 de dezembro de 1999. Brasília, 1999. Disponível em: <http://www.planalto.gov.br/ccivil_03/decreto/d3298.htm>. Acesso em: 13 mar. 2017.

20 BRASIL. Lei 13.146, de 6 de julho de 2015. Brasília, 2015. Disponível em: <http://www.planalto.gov.br/ccivil_03/_ato2015-2018/2015/Lei/L13146.htm>. Acesso em: 13 mar. 2017.

21 BRASIL. Decreto 6.949, de 25 de agosto de 2009. Brasília, 2009. Disponível em: <http://www.planalto.gov.br/ccivil_03/_ato2007-2010/2009/decreto/d6949.htm>. Acesso em: 13 mar. 2017.

22 BRASIL. Constituição da República Federativa do Brasil de 1988. Brasília, 1988. Disponível em: <http://www.planalto.gov.br/ccivil_03/constituicao/constituicaocompilado.htm>. Acesso em: 13 mar. 2017.

23 BRASIL. Lei 13.146, de 6 de julho de 2015. Brasília, 2015. Disponível em: <http://www.planalto.gov.br/ccivil_03/_ato2015-2018/2015/Lei/L13146.htm>. Acesso em: 13 mar. 2017.

Revista de Direito Brasileira | São Paulo, SP | v. 17 | n. 7 | p. 245 - 260 | Mai./Ago. 2017 
Além disso, a pessoa com deficiência tem direito, em igualdade de oportunidades com as demais pessoas, a condições justas e favoráveis de trabalho, incluindo igual remuneração por trabalho de igual valor.

É vedada restrição ao trabalho da pessoa com deficiência e qualquer discriminação em razão de sua condição, inclusive nas etapas de recrutamento, seleção, de contratação, admissão, exames admissional e periódico, permanência no emprego, ascensão profissional e reabilitação profissional, bem como exigência de aptidão plena.

A pessoa com deficiência tem direito à participação e ao acesso a cursos, treinamentos, educação continuada, planos de carreira, promoções, bonificações e incentivos profissionais oferecidos pelo empregador, em igualdade de oportunidades com os demais empregados. É também garantida aos trabalhadores com deficiência acessibilidade em cursos de formação e de capacitação.

As políticas públicas de trabalho e emprego devem ter como finalidade primordial promover e garantir condições de acesso e de permanência da pessoa com deficiência no campo de trabalho (artigo 35 da Lei 13.146/2015) ${ }^{24}$.

Sabendo-se que as diversas formas de trabalho não se resumem ao emprego em sentido mais estrito, os programas de estímulo ao empreendedorismo e ao trabalho autônomo, incluídos o cooperativismo e o associativismo, devem prever a participação da pessoa com deficiência e a disponibilização de linhas de crédito, quando necessárias.

Ainda sobre o tema, na esfera internacional, deve-se ressaltar a Convenção 159 da Organização Internacional do Trabalho, de 1983, aprovada pelo Brasil e promulgada pelo Decreto 129, de 22 de maio de $1991^{25}$, que versa sobre reabilitação profissional e emprego de pessoas com deficiência ${ }^{26}$.

De acordo com o artigo 1, item 2, da referida Convenção 159, todo País-Membro deve considerar que a finalidade da reabilitação profissional é a de permitir que a pessoa com deficiência obtenha e conserve um emprego e progrida nele, promovendo-se, assim, a integração ou a reintegração dessa pessoa na sociedade.

Conforme as condições nacionais, experiências e possibilidades nacionais, cada PaísMembro deve formular, aplicar e, periodicamente, revisar a política nacional sobre reabilitação profissional e emprego de com deficiência (artigo 2). Essa política deve ter por finalidade assegurar que existam medidas adequadas de reabilitação profissional ao alcance de todas as categorias de pessoas com deficiência e promover oportunidades de emprego para as pessoas portadoras de deficiência no mercado regular de trabalho (artigo 3). A mencionada política deve ter como base o princípio de igualdade de oportunidades entre os trabalhadores com deficiência e os trabalhadores em geral. Deve-se respeitar a igualdade de oportunidades e de tratamento também para as trabalhadoras com deficiência.

Frise-se que, de acordo com a parte final do artigo 4 da Convenção 159 da OIT, as "medidas positivas especiais com a finalidade de atingir a igualdade efetiva de oportunidades e de tratamento entre trabalhadores deficientes e os demais trabalhadores, não devem ser vistas como discriminatórias em relação a estes últimos".

Justamente por isso, não são consideradas ilícitas, ou seja, discriminatórias, as chamadas ações afirmativas, buscando alcançar o ideal de igualdade material ${ }^{27}$, como se observa na

24 BRASIL. Lei 13.146, de 6 de julho de 2015. Brasília, 2015. Disponível em: <http://www.planalto.gov.br/ccivil_03/_ato2015-2018/2015/Lei/L13146.htm>. Acesso em: 13 mar. 2017.

25 BRASIL. Decreto 129, de 22 de maio de 1991. Brasília, 1991. Disponível em: <http://www.planalto.gov.br/ccivil_03/decreto/1990-1994/D0129.htm>. Acesso em: 13 mar. 2017.

${ }^{26}$ Cf. MELO, Sandro Nahmias. O direito ao trabalho da pessoa portadora de deficiência. São Paulo: LTr, 2004. p. 92-93.

${ }^{27}$ Cf. BUBLITZ, Michelle Dias. Pessoa com deficiência e teletrabalho: um olhar sob o viés da inclusão social: reflexões à luz do valor social do trabalho e da fraternidade. Porto Alegre: Casa do Advogado, 2015. p. 63.

Revista de Direito Brasileira | São Paulo, SP | v. 17 | n. 7 | p. 245 - 260 | Mai./Ago. 2017 
mencionada previsão legal que fixa cotas em favor de admissão de pessoas com deficiência e beneficiários reabilitados da Previdência Social (artigo 93 da Lei 8.213/1991) ${ }^{28}$.

Nesse caso, o tratamento jurídico diferenciado se justifica em razão da diversidade de certas condições peculiares, na proporção da desigualdade verificada no plano dos fatos ${ }^{29}$.

Como ressalta Celso Antônio Bandeira de Mello:

A lei não pode conceder tratamento específico, vantajoso ou desvantajoso, em atenção a traços e circunstâncias peculiarizadoras de uma categoria de indivíduos se não houver adequação racional entre o elemento diferencial e o regime dispensado aos que se inserem na categoria diferenciada ${ }^{30}$.

Logo, as ações afirmativas representam medidas para corrigir desigualdades e alcançar isonomia de oportunidades e direitos, obtendo-se a integração social de certos grupos mais vulneráveis ou desfavorecidos ${ }^{31}$.

De todo modo, quando a empresa comprova ter empreendido todos os esforços possíveis para o preenchimento do referido percentual de vagas de pessoas reabilitadas ou com deficiência, mas sem obter êxito, pode-se defender o entendimento de que não seria cabível a penalização, justamente por não se ter conseguido alcançar algo que estava fora do seu alcance. Nesse sentido, na jurisprudência do Tribunal Superior do Trabalho, pode-se destacar o seguinte julgado:

Ação civil pública. Vagas destinadas a pessoas portadoras de deficiência. Preenchimento. Art. 93 da Lei 8.213/91. Multa. Indenização por dano moral coletivo. Absolvição. Persistência da obrigação legal. 1. Conquanto seja ônus da empregadora cumprir a exigência prevista no art. 93 da Lei 8.213/91, ela não pode ser responsabilizada pelo insucesso, quando ficou comprovado que desenvolveu esforços para preencher a cota mínima, sendo indevida a multa bem como não havendo falar em dano moral coletivo. 2. A improcedência do pedido de condenação da ré ao pagamento de multa e de indenização por dano moral coletivo fundada no fato de a empresa haver empreendido esforços a fim de preencher o percentual legal de vagas previsto no art. 93 da Lei 8.213/91, não a exonera da obrigação de promover a admissão de pessoas portadoras de deficiência ou reabilitados, nos termos da lei. Recurso de Embargos de que se conhece e a que se dá parcial provimento (TST, SBDI-I, E-ED-RR - 65820089.2009.5.09.0670, Rel. Min. João Batista Brito Pereira, DEJT 20.05.2016).

O $\S 1^{\circ}$ do artigo 93 da Lei 8.213/1991, com redação dada pela Lei 13.146/2015, por seu turno, prevê ainda que a dispensa de pessoa com deficiência ou de beneficiário reabilitado da Previdência Social ao final de contrato por prazo determinado de mais de 90 dias e a dispensa imotivada em contrato por prazo indeterminado somente podem ocorrer após a contratação de outro trabalhador com deficiência ou beneficiário reabilitado da Previdência Social ${ }^{32}$.

${ }^{28}$ Cf. SIMÓN, Sandra Lia. O Ministério Público do Trabalho e a tutela da pessoa portadora de deficiência. In: ARAUJO, Luiz Alberto David (Coord.). Defesa das pessoas portadoras de deficiência. São Paulo: RT, 2006. p. 285287.

${ }^{29}$ Cf. BARBOSA, Rui. Oração aos moços. São Paulo: Hedra, 2009. p. 47: “A regra da igualdade não consiste senão em aquinhoar desigualmente aos desiguais, na medida em que se desigualam. Nesta desigualdade social, proporcionada à desigualdade natural, é que se acha a verdadeira lei da igualdade. [...] Tratar com desigualdade a iguais, ou a desiguais com igualdade, seria desigualdade flagrante, e não igualdade real".

${ }^{30}$ MELLO, Celso Antônio Bandeira de. O conteúdo jurídico do princípio da igualdade. 3. ed., 19. tir. São Paulo: Malheiros, 2010. p. 39.

${ }^{31}$ Cf. CARLOS, Vera Lúcia. Discriminação nas relações de trabalho. São Paulo: Método, 2004. p. $32-34$.

32 BRASIL. Lei 8.213, de 24 de julho de 1991. Brasília, 1991. Disponível em: <http://www.planalto.gov.br/ccivil_03/leis/L8213compilado.htm>. Acesso em: 13 mar. 2017.

Revista de Direito Brasileira | São Paulo, SP | v. 17 | n. 7 | p. 245 - 260 | Mai./Ago. 2017 
Trata-se, na realidade, de hipótese de garantia de emprego, ainda que com certas peculiaridades $^{33}$.

Nesse sentido, prevalece o entendimento de que a inobservância do mencionado dispositivo não gera mera imposição de penalidade administrativa, mas a reintegração do empregado dispensado indevidamente ${ }^{34}$.

Interpretando-se a contrario sensu o $\S 1^{\circ}$ do artigo 93 da Lei 8.213/1991, para os contratos de trabalho por prazo determinado, com duração de até 90 dias, não incide a referida garantia de emprego.

Como observa Sergio Pinto Martins, o "§ $1^{\circ}$ do art. 93 da Lei 8.213/1991 estabeleceu situação envolvendo condição suspensiva: admissão de empregado de situação semelhante. Trata-se de hipótese de garantia de emprego em que não há prazo certo" ${ }^{, 35}$.

Ainda de acordo com o referido autor:

A dispensa do trabalhador reabilitado ou dos deficientes só poderá ser feita se a empresa tiver o número mínimo estabelecido pelo art. 93 da Lei 8.213. Enquanto a empresa não atinge o número mínimo previsto em lei, haverá garantia de emprego para as referidas pessoas. Admitindo a empresa deficientes ou reabilitados em porcentual superior ao previsto no art. 93 da Lei 8.213, poderá a empresa demitir outras pessoas em iguais situações até atingir o referido limite ${ }^{36}$.

Entretanto, há entendimento diverso, que interpreta o mencionado $\S 1^{\circ}$ do artigo 93 de forma distinta, ou seja, não admitindo a dispensa, mesmo que a empresa mantenha em seus quadros, após a despedida, o percentual de deficientes ou reabilitados que a lei exige.

A esse respeito, deve-se salientar que, na jurisprudência do Tribunal Superior do Trabalho, para ser válida a despedida de empregado com deficiência, prevalece a posição quanto à necessidade de serem observados ambos os requisitos ${ }^{37}$, isto é, tanto o referido percentual mínimo, como a contratação de substituto de condições semelhantes ${ }^{38}$.

${ }^{33}$ Cf. GARCIA, Gustavo Filipe Barbosa. Curso de direito do trabalho. 10. ed. Rio de Janeiro: Forense, 2016. p. 825.
${ }^{34}$ Cf. COSTA, Sandra Morais de Brito. Dignidade humana e pessoa com deficiência: aspectos legais trabalhistas. São Paulo: LTr, 2008. p. 207-209.

${ }^{35}$ MARTINS, Sergio Pinto. Direito do trabalho. 22. ed. São Paulo: Atlas, 2006. p. 410.

${ }^{36}$ MARTINS, Sergio Pinto. Direito do trabalho. 22. ed. São Paulo: Atlas, 2006. p. 410.

37 "I - Agravo de instrumento em recurso de revista. Processo eletrônico. Portador de deficiência. Contratação de outro empregado nas mesmas condições. Ausência de prova quanto à observância do percentual mínimo previsto em lei. Reintegração. Constatada a violação do art. 93, caput, da Lei $\mathrm{n}^{\circ}$ 8.213/91, merece provimento o Agravo de Instrumento para determinar o processamento do Recurso de Revista. II - Recurso de revista. Processo eletrônico. Portador de deficiência. Contratação de outro empregado nas mesmas condições. Ausência de prova quanto à observância do percentual mínimo previsto em lei. Reintegração. A regra disposta no parágrafo primeiro do art. 93 da Lei $\mathrm{n}^{\circ}$ 8.213/91 está atrelada ao cumprimento do percentual previsto no caput do referido dispositivo. Deste modo, como a Reclamada não se desincumbiu do ônus de provar a contratação de trabalhadores em cumprimento à cota legal acima aludida a reintegração do Reclamante é medida que se impõe. Recurso de revista conhecido e provido" (TST, 8 $8^{\text {a }}$., RR - 4919-70.2012.5.12.0028, Rel. Min. Márcio Eurico Vitral Amaro, DEJT 13.06.2014).

38 "Reintegração. Observância da previsão contida no art. $93, \S 1^{\circ}$, da Lei $8.213 / 91$ ainda que a reclamada tenha mantido, em seu quadro funcional, o percentual mínimo de empregados reabilitados ou portadores de deficiência. Consoante o disposto no art. 93, caput e $\S 1^{\circ}$, da Lei 8.213/91, a validade da dispensa imotivada de empregado portador de deficiência física condiciona-se à prova de que a empresa preenche o percentual mínimo de vagas ocupadas por empregados portadores de deficiência e que admitiu outro empregado na mesma condição. Desse modo, ainda que a reclamada tenha mantido, em seu quadro funcional, o percentual mínimo de empregados reabilitados ou portadores de deficiência, não deixa de se sujeitar ao disposto no parágrafo $1^{\circ}$ do art. 93 da Lei 8.213/91. Com efeito, eventual exclusão da obrigação de preenchimento de cargos com beneficiários reabilitados ou pessoas portadoras de deficiência só se justificaria diante da impossibilidade de a empresa contratar empregados que se enquadrem como reabilitados ou portadores de deficiência, o que não ficou demonstrado no caso concreto. Sinalese, ainda, que o fato de a parte contratar acima da cota configura ato discricionário do empregador. Recurso de Revista de Direito Brasileira | São Paulo, SP | v. 17 | n. 7 | p. 245 - 260 | Mai./Ago. 2017 
O tema, como se pode notar, é de fundamental relevância na gestão empresarial, ao estabelecer não apenas a exigência de cotas na contratação de trabalhadores pelas empresas, como os requisitos para a validade da despedida de empregado com deficiência, uma vez que, se não forem observados, geram a nulidade da extinção contratual, com o consequente direito à reintegração.

\section{CONCLUSÃO}

A atual sociedade norteia-se essencialmente pelo desenvolvimento e pela disseminação das tecnologias e da comunicação. O surgimento dessa nova sociedade trouxe, portanto, a necessidade de se repensar importantes aspectos relativos à organização social e ao papel do Estado nesse contexto contemporâneo. Essa necessidade fez com que a questão da inclusão das pessoas com deficiência tomasse relevo e fosse reconhecida em normas internacionais e nacionais.

Avançando no processo de construção de uma sociedade que respeite a diversidade, aprova-se com força de emenda constitucional a Convenção sobre os Direitos das Pessoas com Deficiência e seu Protocolo Facultativo, cuja finalidade não foi apenas instituir novos direitos humanos e liberdades fundamentais para as pessoas com deficiência, mas garantir que elas possam desfrutá-los em igualdade de condições, sem discriminação. Em harmonia com esse direito fundamental ao acesso, foi aprovada a Lei 13.146, de 6 de julho de 2015, que institui a Lei Brasileira de Inclusão da Pessoa com Deficiência (Estatuto da Pessoa com Deficiência). E, para que isso ocorra, reforça-se a ideia de que as inúmeras barreiras, inclusive as encontradas no ambiente laboral, não devem impedir a possibilidade de que essas pessoas usufruam os seus direitos, notadamente ao trabalho, o que é enfatizado por meio da reserva de cotas nas empresas.

$\mathrm{O}$ direito à acessibilidade é, portanto, uma exigência constitucional que surge, atualmente, como um direito fundamental, para que a pessoa com deficiência ou mobilidade reduzida possa desfrutar das mesmas oportunidades, a saber: educação, habitação, lazer, cultura, novas tecnologias da informação, comunicação e inclusão no mercado de trabalho.

$\mathrm{O}$ direito fundamental de acesso à pessoa com deficiência foi amplamente assegurado em nosso ordenamento jurídico. Todavia, para que essas pessoas possam realizar de modo pleno e irrestrito esse direito fundamental, sobretudo no ambiente laboral, é essencial que lhes seja assegurada a capacidade de utilizar dos espaços arquitetônicos, mobiliários, equipamentos urbanos, transportes, informação e comunicação, assim como outras medidas específicas, como a previsão de cotas nas empresas.

Nesse contexto, o Estatuto da Pessoa com Deficiência prevê que a inclusão da pessoa com deficiência no trabalho deve ocorrer por meio da colocação competitiva em igualdade de oportunidades com as demais pessoas. Para que isso ocorra, devem ser seguidas as normas presentes na legislação trabalhista e previdenciária, observando-se as regras e técnicas referentes à acessibilidade, com o fornecimento de recursos de tecnologia assistiva e de adaptação razoável no ambiente de trabalho, inclusive com o cumprimento da Lei 8.213/1991, ao impor a obrigatoriedade (para as empresas com 100 ou mais empregados) do preenchimento de cargos com beneficiários reabilitados ou com deficiência habilitados, bem como estabelecer restrições à dispensa desses empregados (artigo 93).

Observa-se, assim, que não faltam em nosso ordenamento jurídico leis que assegurem o referido direito ao acesso. Somente a normatividade desses direitos, entretanto, não é o bastante para se garantir a concretização efetiva da acessibilidade às pessoas com deficiência, inclusive quanto ao mercado de trabalho, exigindo-se posturas mais ativas por parte do poder público e da

revista conhecido e provido" (TST, $7^{\mathrm{a}}$ T., RR - 10740-12.2005.5.17.0012, Rel. Min. Delaíde Miranda Arantes, DEJT 05.04.2013).

Revista de Direito Brasileira | São Paulo, SP | v. 17 | n. 7 | p. 245 - 260 | Mai./Ago. 2017 
sociedade como um todo, como a qualificação das pessoas com deficiência, para que possam desempenhar as suas atividades profissionais de modo mais justo e adequado.

Por fim, é nítido que o sistema jurídico em vigor procura reparar a falta de inclusão das pessoas com deficiência na sociedade, notadamente quanto ao direito ao trabalho, dando oportunidade de acesso ao ambiente laboral, em suas mútuas interações com o meio ambiente em seu todo. Todavia, observam-se, ainda, dois grandes desafios, quais sejam: informar à população, em especial aos deficientes, sobre todos os seus direitos, assim como torná-los efetivos e amplamente assegurados nos diversos âmbitos da vida em sociedade.

\section{REFERÊNCIAS BIBLIOGRÁFICAS}

BARBOSA, Rui. Oração aos moços. São Paulo: Hedra, 2009.

BRASIL. Constituição da República Federativa do Brasil de 1988. Brasília, 1988. Disponível em: <http://www.planalto.gov.br/ccivil_03/constituicao/constituicaocompilado.htm>. Acesso em: 13 mar. 2017.

BRASIL. Decreto 129, de 22 de maio de 1991. Brasília, 1991. Disponível em: <http://www.planalto.gov.br/ccivil_03/decreto/1990-1994/D0129.htm>. Acesso em: 13 mar. 2017.

BRASIL. Decreto 2.596, de 18 de maio de 1998. Brasília, 1998. Disponível em: <http://www.planalto.gov.br/ccivil_03/decreto/D2596.htm>. Acesso em: 13 mar. 2017.

BRASIL. Decreto 3.298, de 20 de dezembro de 1999. Brasília, 1999. Disponível em: <http://www.planalto.gov.br/ccivil_03/decreto/d3298.htm>. Acesso em: 13 mar. 2017.

BRASIL. Decreto 6.949, de 25 de agosto de 2009. Brasília, 2009. Disponível em: <http://www.planalto.gov.br/ccivil_03/_ato2007-2010/2009/decreto/d6949.htm>. Acesso em: 13 mar. 2017.

BRASIL. Lei 7.573, de 23 de dezembro de 1986. Brasília, 1986. Disponível em: <http://www.planalto.gov.br/ccivil_03/leis/1980-1988/L7573.htm>. Acesso em 13 mar. 2017.

BRASIL. Lei 8.213, de 24 de julho de 1991. Brasília, 1991. Disponível em: <http://www.planalto.gov.br/ccivil_03/leis/L8213compilado.htm>. Acesso em: 13 mar. 2017.

BRASIL. Lei 9.537, de 11 de dezembro de 1997. Brasília, 1997. Disponível em: <http://www.planalto.gov.br/ccivil_03/leis/19537.htm>. Acesso em: 13 mar. 2017

BRASIL. Lei 13.146, de 6 de julho de 2015. Brasília, 2015. Disponível em: <http://www.planalto.gov.br/ccivil_03/_ato2015-2018/2015/Lei/L13146.htm>. Acesso em: 13 mar. 2017.

BUBLITZ, Michelle Dias. Pessoa com deficiência e teletrabalho: um olhar sob o viés da inclusão social: reflexões à luz do valor social do trabalho e da fraternidade. Porto Alegre: Casa do Advogado, 2015. 
CARLOS, Vera Lúcia. Discriminação nas relações de trabalho. São Paulo: Método, 2004.

COSTA, Sandra Morais de Brito. Dignidade humana e pessoa com deficiência: aspectos legais trabalhistas. São Paulo: LTr, 2008.

DELGADO, Mauricio Godinho. Curso de direito do trabalho. 15. ed. São Paulo: LTr, 2016.

GARCIA, Gustavo Filipe Barbosa. Curso de direito do trabalho. 10. ed. Rio de Janeiro: Forense, 2016.

GRECO, Marco Aurélio. Transações eletrônicas: aspectos jurídicos. Revista de Direito Bancário do Mercado de Capitais e da Arbitragem, São Paulo, RT, v. 8, p. 60-85, abr./jun. 2000.

GUGEL, Maria Aparecida. Do Direito ao Trabalho. In: LEITE, Flávia Piva Almeida; RIBEIRO, Lauro Luiz Gomes; COSTA FILHO, Waldir Macieira (Coord.). Comentários ao Estatuto da Pessoa com Deficiência. São Paulo: Saraiva, São Paulo, 2016.

LEVY, Pierre; AUTHIER, Michel. As árvores de conhecimentos. São Paulo: Escuta, 1995.

LEVY, Pierre. As tecnologias da inteligência: o futuro do pensamento na era da informática. Rio de Janeiro: Editora 34, 1993.

. O que é o virtual? São Paulo: Editora 34, 1996.

. A ideografia dinâmica: para uma imaginação artificial? Lisboa: Instituto Piaget, 1997.

. Cibercultura. Tradução de Carlos Irineu da Costa. São Paulo: Editora 34, 2001.

. A máquina universo: criação, cognição e cultura informática. São Paulo: $\underline{\text { Artmed, } 1998 .}$

$\underline{2000 .}$.

. A inteligência coletiva: por uma antropologia do ciberespaço. 3. ed. São Paulo: Loyola,

. Filosofia world: o mercado, o ciberespaço, a consciência. Lisboa: Instituto Piaget, 2000.

. A Conexão Planetária: o mercado, o ciberespaço, a consciência. São Paulo: Editora 34, $\underline{2001 .}$

. Ciberdemocracia. Lisboa: Instituto Piaget, 2003.

. O futuro da internet. São Paulo: Paulus, 2010.

. O fogo liberador. São Paulo: Iluminuras, 2007.

MARQUES, Garcia; MARTINS, Lourenço. Direito da informática. Coimbra: Almedina, 2000.

Revista de Direito Brasileira | São Paulo, SP | v. 17 | n. 7 | p. 245 - 260 | Mai./Ago. 2017 
MARTINS, Sergio Pinto. Direito do trabalho. 22. ed. São Paulo: Atlas, 2006.

MELLO, Celso Antônio Bandeira de. O conteúdo jurídico do princípio da igualdade. 3. ed., 19. tir. São Paulo: Malheiros, 2010.

MELO, Sandro Nahmias. $O$ direito ao trabalho da pessoa portadora de deficiência. São Paulo: LTr, 2004.

MORÓN LERMA, Esther. Internet y Derecho Penal: "hacking" y otras conductas ilícitas en la red. Revista de Derecho y Processo Penal, Pamplona, Aranzadi, n. 1, p. 1-147, 1999.

SASSAKI, Romeu Kazumi. Inclusão: construindo uma sociedade para todos. 3. ed. Rio de Janeiro: Editora WVA, 1999.

SIMÓN, Sandra Lia. O Ministério Público do Trabalho e a tutela da pessoa portadora de deficiência. In: ARAUJO, Luiz Alberto David (Coord.). Defesa das pessoas portadoras de deficiência. São Paulo: RT, 2006. p. 280-294. 